\title{
Mainstreams in the Development of European Tort Law: A Front-Line Snapshot
}

\author{
Bernhard A. Koch \\ Institut für Zivilrecht der Universität Innsbruck, Innrain 52, A-6020 Innsbruck, Austria. \\ E-mail: bernhard.a.koch@uibk.ac.at
}

The author presents an overview of some common trends in European tort law systems which are evidenced by significant case law or legislation in the past 5 years.

The Geneva Papers (2006) 31, 270-276. doi:10.1057/palgrave.gpp.2510072

Keywords: tort law codification; public liability; human rights; non-pecuniary loss; right to privacy; right to life

\section{Introduction}

The remarks ${ }^{1}$ that follow shall weave together some of the threads laid out by the collected contributions to an annual publication which covers the most recent tort law developments in almost all European jurisdictions each year. These tort and insurance law yearbooks ${ }^{2}$ contain the extended versions of presentations given at the "Annual Conference on European Tort Law" in Vienna, which comes into its fifth season in $2006 .^{3}$

Throughout these past years, it has been remarkable to notice how certain recurring themes eventually (and often simultaneously) show in almost all jurisdictions, even if unrelated by legal family. There indeed seem to be mainstreams in the development of European tort law, even though the enthusiasm of judges and legislators to look across the boundaries of their own jurisdictions does not seem to have heightened in a way that could explain such common trends.

\section{Tort law (re-) codification}

The most evident developments in a legal system are of course amendments and additions to its written laws. While such legislative changes have reshaped tort law every now and then throughout Europe and as such would not be worth mentioning,

\footnotetext{
${ }^{1}$ The text is based on a presentation given at the occasion of the Annual Liability Regimes Conference in Munich 2005. Both form and style of a manuscript for an oral presentation have been preserved.

${ }^{2}$ The first four volumes have been published so far: Koziol and Steininger (2002-2005). All information in the text on developments in specific countries is drawn from reports submitted to these publications of the respective calendar year and is therefore not cited separately.

${ }^{3}$ The conference is jointly organized by the European Centre of Tort and Insurance Law (ECTIL, http:// www.ectil.org) and the Research Unit for European Tort Law of the Austrian Academy of Sciences (http://www.etl.oeaw.ac.at). The next conference will take place from April 20-22, 2006 in Vienna.
} 
it is quite striking that the willingness to revise tort law as a whole has been spreading throughout Europe over the past years.

It may come as no surprise that most countries in the eastern part of Europe have reconsidered (though not necessarily fundamentally changed) their tort laws or are about to do so in the course of comprehensive adjustments to their private law systems as a whole, starting in the 1990s. The new Slovenian Code of Obligations was published in 2001, for example. In the same year, the new Estonian Law of Obligations Act (Võlaõigusseadus) was passed, as was the new Lithuanian Civil Code. The recodification of private law in the Czech Republic is still on its way: after the rejection of an earlier draft from the mid-1990s, a second attempt started in 2001. The Polish reform process has also not yet been completed, even though several amendments have already been passed. A draft proposal of the new Hungarian Civil Code was published in 2002.

During the same time period, the Scandinavian countries also updated their legislation, particularly with respect to the compensability of non-pecuniary loss. Major amendments to the Danish Erstatningsanvarsloven came into force on July 1, 2002, while significant changes to the Swedish Skadestandslagen were made already half a year earlier. An important reform in Finland just became effective in 2006.

Members of the Germanic legal family were equally active recently. The 2002 tort reform act in Germany may have been in the shadow of the re-promulgation of the BGB as a whole that same year, but still brought about very important changes, for example in the area of non-pecuniary loss. The comprehensive draft revision of Swiss tort law was published in 2000 (though it unfortunately seems to have come to at least a temporary halt ever since). The Austrian reform commission has just presented its draft of a complete recodification of Austrian tort law in May 2005.

The most recent European reform project is on the move in France; an avant-projet of a complete revision of the French law of obligations was published last fall. ${ }^{4}$

\section{Public liability}

Apart from changes to tort law as a whole, specific areas thereof have also been amended or regulated anew. One such area is public liability. New legislation in this field was passed in Estonia (2001), Belgium and Slovakia (both 2003) as well as in Poland (2004).

These few statutes by themselves would not be enough to be called a trend, had there not been considerable activity in this field in courts and in other forums throughout Europe, not counting (and disregarding in the following) state liability on the European level.

In fact, of all cases reported from all over Europe in the past 5 years, a strikingly high number dealt with claims against the public authorities in general and the state in particular, not only in the Eastern European countries, which seem to be in the lead in this respect, however. Noteworthy decisions in this field have been reported from

\footnotetext{
${ }^{4}$ Catala (2005).
} 
almost all jurisdictions. In the Netherlands, for example, this development was strong enough to encourage the launch of a new journal in 2002 devoted entirely to this aspect of tort law.

On a more general level, public response to recent large-scale losses (not only those caused by natural catastrophes) has confirmed once again that citizens seem to view their states as providers of unlimited insurance against any risk of life with the deepest pocket of them all (though nobody seems to realize who fills these pockets). At least as long as media attention to the respective harmful event is guaranteed, politicians feel the urge to support state involvement in various kinds of compensation regimes, from catastrophe funds to terrorism risk pools. ${ }^{5}$ Not only the latter, but even more so indemnification schemes introduced to cover certain risks in the medical field and most importantly - state contributions to indemnify victims of singular tortious acts (be it the Prestige oil spill case or the explosion of the fireworks factory in Enschede) are signs flashed to the public that the bigger the loss - even if undoubtedly attributable to a tortious act of a wrongdoer - the more likely the state will step in. This is of course a strong incentive for those who feel they have been wronged to seek indemnification from the state even in singular and smaller-scale loss scenarios. This may very well be at least one explanation for the growing tendency to sue public authorities, for example for failure to properly enforce a certain regulation, even though the immediate cause of the loss was a violation of that rule by an individual. The old saying of casum sentit dominus is apparently on the edge of being converted to casum sentit res publica.

\section{Tort law and human rights}

The growing awareness of human rights as a basis of claims by individuals has led to several noticeable changes in substantive tort law. The jurisdiction most obviously affected is England, where the Human Rights Act of 1998 "has caused a re-thinking of English law's approach to liability in negligence", ${ }^{6}$ apart from creating a new basis for claims against public authorities, which builds the bridge to the previous topic. But even on the continent, there is a marked new awareness of human rights, particularly of those which have so far not yet been considered to be compensable in monetary terms, at least in some jurisdictions. The (re)discovery of the right to privacy as well as the somewhat vague legal concept of human dignity has inspired lawyers and legislators in many countries to press ahead with (what they claim) the protection of such rights, sometimes, however, at the cost of infringing upon other rights. One example may be a 2003 amendment to the Austrian civil code, introducing liability for invasions of privacy and allowing for compensation of non-pecuniary loss even though other (and higher-ranking) personality rights have so far not yet received the same degree of protection (apart from the fact that the new provision as it stands unfoundedly overprotects the media).

\footnotetext{
${ }^{5}$ On the various responses to the risks of terrorism, see Koch (2004); on catastrophic losses in general see Faure and Hartlief (2006).

${ }^{6}$ Lunney and Oliphant (2003, p. 129).
} 
A related trend, apparently originating in the Romanic legal family, is a redefinition of bodily injury from measurable violations of one's bodily integrity (which can be remedied in monetary terms) to damage to health in a broader sense, which recognizes even minor interferences as a legally relevant harm, though it may only lead to nominal damages. The latter point of view focuses more on the violation of the victim's interest as such rather than on the efforts needed to indemnify her, which serves as an indirect way of quantifying her loss under the former angle. It still remains to be seen which perspective will ultimately prevail, though the choice between the two will most likely not have a tremendous influence on the outcome of individual cases. It would nevertheless be very helpful for the comparability of European tort laws in the future if one could at least find a common nomenclature, which seems to be an unresolved problem even on the national levels at present. $^{7}$

The reinforced awareness of human rights is also dominating the discussion about new ethical problems which have arisen before or undoubtedly will have to be addressed from a tort law perspective throughout Europe in the future.

The right to life was already at the centre of debates surrounding the consequences of new reproduction techniques and failures thereof. A previously hot topic, it is now apparently cooling off after the issue has been settled over the past few years in almost all European countries. While the availability of damages for wrongful life has been denied by most courts, ${ }^{8}$ the parents' claims for compensation for wrongful birth has been acknowledged by most jurisdictions in the meantime. ${ }^{9}$

The right to life may be on top of the tort law agenda again, however, once problems related to euthanasia will make it to the compensation arena. What about claims for wrongful life by someone who wanted to put an end to his suffering but did not succeed despite (lawful) professional assistance? What about claims by surviving relatives built upon informed consent problems? While it is not yet clear when such cases will be decided, I am strongly convinced that they will sooner or later arrive on the scene.

\section{Non-pecuniary loss}

Turning now to the consequences of tortious activities, clearly the number one trend shaping tort law these past years concerned the recoverability of non-pecuniary loss. ${ }^{10}$

\footnotetext{
${ }^{7}$ See, e.g., Lambert-Faivre (2003).

${ }^{8}$ While the French Conseil d'État had denied it, the Cour de cassation had awarded compensation on that basis in the notorious arrêt Perruche, but was subsequently overruled by specific legislation excluding a claim "for the mere fact of one's own birth". The Austrian, German, Italian, Portuguese and Spanish supreme courts have at least obiter (if not directly) ruled out the compensability of one's own existence, whereas the Dutch Supreme Court in a 2005 ruling in the so-called "Kelly case" (Hoge Raad 18.3.2005, no. $\mathrm{C} 03 / 206 \mathrm{HR}$ ) has circumvented the issue by redefining the non-pecuniary loss of the baby for which damages were awarded.

${ }^{9}$ One exception may be Spain, where a claim of such kind was denied in a 2002 case, but at least partly acknowledged in a 2003 decision. Wrongful life/wrongful birth case references can be found in all volumes of the Yearbook.

${ }^{10}$ For the developments before the first yearbook publication, see Rogers (2001).
} 
These developments can be summarized with the two slogans "more claimants" and "higher amounts".

\section{More claimants}

The first catchphrase refers to the fact that more and more categories of people affected by a tort beyond the immediate victim are becoming eligible to claim damages in their own right (or par ricochet, depending on the respective jurisdictions' point of view). The order in which additions to this list of secondary victims have been or are being made throughout Europe may vary as may the speed of this expansion, but the various multi-layer facets of this trend universally include the following shifts, which naturally overlap:

- While originally only the closest relatives belonging to the family in the legal sense were entitled, if any, the necessary relationship between the primary and the secondary victim has tended to get looser. First, for example, with the definition of "family" being extended beyond the direct line, it is no longer necessary to require connections established by marital bonds (with some jurisdictions still split internally, as is Portugal with the Supreme Court insisting on the former requirement and the Constitutional Court being more generous). Within the group of lifetime companions, initially only heterosexual relationships were acknowledged, but subsequently also partners of the same sex. Ultimately, the development has moved towards including persons who are not necessarily related in either narrower or broader sense, but just have some sort of close affiliation with the primary victim that in the eyes of the judges sufficiently supports their claims to have suffered a non-pecuniary loss.

- Apart from the formal type of relationship between the primary and the secondary victim, the quality of that relationship is also of the essence. Some jurisdictions simply presume actual closeness and imply this from the formal type of affiliation, or require actual cohabitation. Others (such as Austria or Finland) add this as a (restrictive) additional test and deny compensation even to close family members if their actual relationship is not considered to be strong enough in the sense of tight emotional bonds.

- Even if a secondary victim was close to the immediate victim in the aforementioned sense, she might still not be entitled to compensation if she had not been at the scene of the harmful incident. Eventually, also persons who had not witnessed the accident could claim damages.

- Originally, most jurisdictions started off indemnifying only those secondary victims who had suffered some measurable (either bodily or mental) injury themselves, such as a nervous shock (and insofar were actually primary victims, but with a more remote cause). Later on, grief and bereavement down to a lesser degree of emotional response may suffice.

- Finally, the question remains whether non-pecuniary loss of secondary victims is awarded only in cases of fatal accidents, or if a "mere" bodily injury (be it severe or of a lesser kind) of the primary victim suffices. Most jurisdictions probably still 
belong to the first category, though some have already made the move towards the more generous conception (such as France, Belgium or Switzerland).

All European countries can be placed somewhere into this matrix, and all still seem to be on the move, with some taking steps very slowly, if at all (such as the Netherlands or Germany, which are both still very restrictive when it comes to claims by secondary victims).

\section{Higher amounts}

Another development which could be observed all over Europe in these past few years was quite a remarkable increase in the amounts paid out in compensation of nonpecuniary loss, though probably more of a "trend within this trend" as damages in severe cases have risen more dramatically than in others. The most noticeable movement was therefore rather at the top of the scale. We are not talking of mere adjustments to inflation here (which were not worth mentioning at all), but of truly significant "jumps" to considerably higher levels. In a 2002 quadriplegia case, for example, the Austrian Supreme Court awarded an amount for pain and suffering which exceeded the previous top figure by 50 per cent. This does not mean, however, that the gaps between the different levels of compensation in various countries are closing, as all are reconsidering their previous limits. Just one year before, a German case, for example, had pulverized the previous limits there and set the bar at a new alltime record of $€ 500,000$, which was (and still is) double the new Austrian maximum.

This does not mean, however, that the awards for pain and suffering will continue to rise as dramatically in those jurisdictions which have already undergone such radical changes. The courts have made clear that such new maximum amounts shall set the standard for many years to come, with only slight adjustments to inflation, if necessary.

\section{Keeping the floodgates wide open?}

The first publication of the European Group on Tort Law ${ }^{11}$ dealt with "the limits of liability", expressing in its subtitle a hope for "keeping the floodgates shut". ${ }^{12}$ The trends throughout Europe (just described) seem to point in the opposite direction: Liability tends to increase not only in monetary terms, but also the grounds of action are apparently ever expanding.

Still, there is no point in lamenting about past reforms, as they cannot be reversed anyhow. Very often, changes already passed or on the way had been overdue and only became noteworthy as they resolved a backlog of necessary amendments. Nevertheless, it appears to be crucial to stay alert to such trends, as they occasionally seem to lead into a slippery slope of developments which do not always produce desirable results.

\footnotetext{
11 http://www.egtl.org.

12 Spier (1996, 1998).
} 
The best way to react to mainstreams in the development of tort law is to start their flow, which allows control over both direction and speed; the second best option is to at least actively influence their regulation. Letting rivers run wild always causes flooding.

\section{References}

Catala, P. (2005) Rapport sur l'avant-projet de réforme du droit des obligations et du droit de la prescription, available at http://www.justice.gouv.fr/publicat/rapport/RAPPORTCATALASEPTEMBRE2005.pdf, accessed 10 January 2006.

Faure, M. and Hartlief, T. (2006) Financial Compensation for Victims of Catastrophes, Vienna: Springer.

Koch, B.A. (2004) Terrorism, Tort Law and Insurance, Vienna: Springer.

Koziol, H. and Steininger, B. (2002) European Tort Law 2001, Vienna: Springer.

Koziol, H. and Steininger, B. (2003) European Tort Law 2002, Vienna: Springer.

Koziol, H. and Steininger, B. (2004) European Tort Law 2003, Vienna: Springer.

Koziol, H. and Steininger, B. (2005) European Tort Law 2004, Vienna: Springer.

Lambert-Faivre, Y. (2003) 'L'indemnisation du dommage corporel', available at http://www.justice.gouv.fr/ publicat/syntheseindemcorp.pdf, accessed 10 January 2006.

Lunney, M. and Oliphant, K. (2003) Tort Law, 2nd edn., Oxford: Oxford University Press.

Rogers, W.V.H. (2001) Damages for Non-Pecuniary Loss in a Comparative Perspective, Vienna: Springer. Spier, J. (1996) The Limits of Liability: Keeping the Floodgates Shut, The Hague: Kluwer Law International. Spier, J. (1998) The Limits of Expanding Liability. Eight Fundamental Cases in a Comparative Perspective, The Hague: Kluwer Law International.

\section{About the Author}

Bernhard A. Koch teaches at the Institute of Private Law, University of Innsbruck, Austria. He is also the vice-director of the Research Unit for European Tort Law of the Austrian Academy of Sciences. 